\title{
A review of Till Düppe's The making of the economy: a phenomenology of economic science. Plymouth: Lexington Books, 2011, 241 pp.
}

\author{
ANTONIO CALLARI \\ Franklin and Marshall College
}

As its subtitle indicates, this book is a reflection on the idea of economics as "science" from the vantage point of the phenomenological tradition in philosophy. Düppe asks a two sided question: what in the life-world ${ }^{1}$ creates the opportunity for the expertise that might go by the name of "economic science"; and what interests have led would-be economists to respond. The book is very interesting from a number of vantage points within economics itself, giving depth and perspective to themes in the history of economics, to economic theory and methodology, and to contemporary conversations about what "economics" is (or is not). Philosophy, it turns out, can still yield useful insights, and this book yields an abundance of them. ${ }^{2}$

Düppe begins the book with Husserl's critique of modern science as an enterprise that forgets the primal, existentialist meaning-making character of thought/theory. He argues that in economics this forgetting happens through a 'formalism' (of theory) and a 'structuralism' (of economy). He then goes on, in the second part of the book, to perform a phenomenological scan (details to follow) on various chapters of the history of economic discourse, starting with the case of oikovouia (economic life without "economics") and ending with the current state of affairs, in which he sees a dissolution of "economic science". Düppe approves of this dissolution, seeing in it a victory of the phenomenological instinct; seeing in it, that is, the possibility for

\footnotetext{
1 The "life-world" is Edmund Husserl's term for the primal, existential conditions out of which humans make meaning. The life-world comes before meaning. The phenomenological tradition is thus different from any tradition (even hermeneutics) which would speak of meaning as inscribed in some pre-given situation: "[...] the life world is not the original world, but rather the originating world. [...] The life-world is not the world that 'makes' sense, but it is the locus of the need to make sense" (p. 32).

${ }^{2}$ There are, of course, some points of contact between Düppe's approach and work in the philosophy/methodology of economics tradition. But whereas the latter inquires into what the standards of authority/validity might be, Düppe raises existential questions about the nature of, and need for, such standards.
} 
economic discourse to return to the life-world, to the horizons of social policy and to the realm of existential meaning.

Central to Düppe's argument are two points. The first point is that the idea of "the economy" is totally internal to economic science. Far from having a natural correspondence in the world, the idea was created, in theoretically precise ways, in response less to the needs of citizens for something with which to make sense of their lives, and more to the need of economic science for an object of its own. The second point is that, for modern science, the loss of connection to the life-world (to the meaning making nature of thought) comes in the form of a claim to objectivity, in the form of the figure of the scientist as an overcoming, at the limit, of subjectivity, of human frailties. These two points intersect, and, in line with Husserl's philosophical transformation of the claim of objectivity into a charge of objectification, Düppe argues that the function of the idea of the economy has been not only to give an "object" to the science, but also, and most importantly, to guarantee the ethos (and pathos) of the economist as "scientist". As such, the economist/scientist is the figure who is above the ordinary interests and passions of economic agents; who is objective and calm; who is detached from "the world" except as something to purify into an object of knowledge; who is, or strives to be, above suspicion.

In the end, Düppe argues, both "the economy" and the economist qua scientist prove untenable. He sees evidence of an end to "economic science" in the lack of any exclusively "economic" axis shaping "research" in economics departments-a lack, a void, filled in by a panoply of themes/objects/questions taken from other fields: psychology, mathematics, history, philosophy, sociology, anthropology. For him, the proof of the dissolution of economics occurring under our very eyes lies in the fact that researchers so engaged could migrate from economics departments to departments in these other fields without any resulting loss of content for their specific research projects. Economic science dissolves in its own terms, under the imperative of an object (a research framework) it can no longer lay exclusive claim to.

To support his conclusion, Düppe constructs a narrative of the history of economics as an almost teleological process. ${ }^{3}$ Economists,

\footnotetext{
${ }^{3}$ I write "almost" because Düppe is too sophisticated to claim some systemic necessity to the history of ideas (that would be in open conflict with phenomenology), and yet his narrative does give a certain substantive weight to the imperative of modern
} 
once having imagined "the economy" in order to give their science an object (and themselves authority), but having also to obey the imperative to inoculate knowledge from the contaminations of interests and passions, of politics, culture, ideology, or even from the mere suspicion of such contamination, were led, by the force of this imperative, to empty their "object" ("the economy") of all substantive contents which could act as channels of contamination. The product of this evisceration of life from "the economy", Düppe argues, is the highly formalist, structured yet empty, concept of Debreuvian general equilibrium in which questions about the nature of economic agents and processes are muted.

Having thus come to lose all specific content, Düppe concludes, economics, as science, has no reason, indeed no right, to exist. He calls for an institutional sanctioning of the dissolution of economic science, counseling the "critics within" to call for the abolition of economics departments. The demolition of these houses of economic science would allow those so interested to leave behind the pathos of disinterest (objectivity) that the modernist ethos of science cultivated and to move on to being able to face questions of meaning and engage in discussions of interests.

At the end of this review, I will return to this question of the end of economic science and economics departments. The reader, however, first deserves a flavor of the intellectual yield of the book's phenomenological history. Düppe is quite rigorous in his philosophical refusal to take "economics" as a given, which is something almost impossible to do in any historical narrative written from "within" (any position "in") economics. His concerns, therefore, are not with analytical issues per-se, but with questions of the constitution and meaning of economics in society at large, and his insights here are valuable and refreshing.

In his chapter on non-market societies, Düppe explains the fundamental difference between "economy" and "oikovouia" (the former embedded in a structural order which sublates the political, cultural, and social to the "economic"; the latter deployed in a temporal order which preserves those distinctions) in a way which adds significantly to the work of, e.g., Karl Polanyi, or Keith Tribe (though Düppe does not cite them). In his chapter on the rise of "the economy" in the the fate of modern science" (p. 36). There is a porous line between "fate" and "telos." 
seventeenth and eighteenth centuries, Düppe puts the accent not on the development of trade per se, as standard histories do, but on the nature of the relationships of merchants (that historically mistrusted, suspicion-arousing group) to the cultural and political channels in the societies of those times. What potentiated the idea of the economy in Britain was not the extensive nature of trade patterns per se, but the fact that there-unlike, e.g., the case of France-merchants were not under political authority and were thus subject to "suspicion" (as a special interest group). It was in that place therefore that a need could be shaped, or even invented, for some standard, some place (ethos) from whence the suspicion could be contained. The budding anonymity of the economy offered the conditions for the erasure of that environment of suspicion. Thus, what gave the Wealth of nations its rhetorical power (and began the analytical project of "economics") was not Smith's philosophical/ analytical bent-important as that might be in other respects-but the cover of "disinterestedness" Smith's academic garb could provide.

After Smith the fortunes of the likes of Ricardo and Malthus, or Marx (or, for a yet later horizon, even Keynes) do not play much of a role in Düppe's narrative. I will return to this omission later; for now the point is that, for Düppe, the analytical work of these figures did not contribute to the separation of economic "science" from politics, but rather worked against this separation. What Düppe's phenomenological scan highlights instead, as the challenge for the ethos of modernist science over the course of the short century from 1846 to $1932,{ }^{4}$ was the new wave of suspicion about economics created by the popularization of political economy by the likes of Harriet Martineau and by the passionate political and philosophical pronouncements of various socialist traditions.

By 1932 such suspicion could again be muted by reference to Lionel Robbins's Essay on the nature and significance of economic science. The power of the Essay lay not so much in its definition of economics per se ("Economics is the science which studies human behaviour as a relationship between ends and scarce means which have alternative uses"), but in the turn toward the de-substantiation of economics that it confirmed: "In hindsight, Robbins's essay was successful not because

\footnotetext{
${ }^{4}$ With the repeal of the Corn Laws in the UK, 1846 inaugurated the official doctrine of free trade. 1932 saw the publication of Lionel Robbins's Essay on the nature and significance of economic science.
} 
economists came to an agreement about the scope of their discipline, but because this question began to lose relevance" (p. 137). ${ }^{5}$

Of the various skirmishes that have punctuated the history of economics, the one Düppe focuses on is the socialist calculation debate. This particular debate, according to him, encapsulates both the instinct of economic discourse to be politically relevant (by speaking about the nature of different economic systems) and the contrary instinct of "science" to run away from any substantive concept of economic processes. It was the latter instinct that was eventually to prevail. The fact that, throughout the debate, both socialism and capitalism were essentially conceived as two modes of a (single) structured economic rationality (the anarchic market or the controlled market-but an economy conceived as a structure of markets in either case) was not conducive to a discourse of difference.

The debate did present opportunities for addressing substantive matters of economic organization nonetheless; and a certain Friedrich Hayek even seized them with his conception of the market as process (not structure). But, alas, under the pressures of the Cold War, and the need to allay the suspicions that war again fomented, economics presented itself increasingly as a-political. The debate, Düppe argues, therefore eventually ceased to attract "economists". What instead became the vogue in economic science was a turn to formalism, presenting the market as a pure, mathematically formal system of prices, without references to actual agencies, market processes, and the like.

Gerald Debreu is the crucial figure in Düppe's narrative of the inclination toward discreetness which compelled economics first to invent "the economy" and then to empty it of all concreteness. The book presents a deep personality sketch of Debreu (drawn from the recollections of his daughter, Chantal Debreu, and from accounts of Debreu's stay at the Cowles Foundation after WWII) as a figure of extreme discreetness. Debreu, Düppe writes,

did not share the hopes regarding explanatory purposes of general equilibrium theory that his work with Arrow had caused. An equilibrium, for him, had no referential meaning but was a condition of a consistent theory [...]. "In proving existence one is not trying

${ }^{5}$ For Düppe, the key step toward this liberation of "science" from politics, which Robbins's Essay sanctioned, was John Stuart Mill's attempt to divorce the "science" of production from the "art" of distribution. 
to make a statement about the real world, one is trying to evaluate the model", he explained later in his life (p. 171, emphasis added).

Düppe also quotes Debreu on the reactions to general equilibrium (G.E.) of, on the one hand, liberal economists who saw in it proof of the invisible hand, and, on the other hand, Marxist economists who saw in it the impossible conditions G.E. required: "I simply took the following stance: You can derive whatever conclusions you want from the assumptions. If it satisfies liberal economists and Marxists, too: Perfect!" (p. 175). It would indeed seem that, for Debreu at least, the question of capitalism or socialism had passed! And Düppe sees this as symbolic in toto of the discreetness embedded in the genetic code of economic science.

And so, after the 1970s, we come to our own times, in which economics, having gained its rigor and lost its soul, limps along. Arguing against the positions of some, e.g., John Davis and David Colander, Düppe does not see in the turn to complexity, behavioralism, experimentalism, game theory, and so on, a resurgence of the possibilities for real science in economics. For him, referring to an orthodox/neo-classical tradition which no one (supposedly) ${ }^{6}$ practices anymore is not, as it is for Davis and Colander, inappropriate, or anachronistic. Düppe agrees that the "orthodox/neo-classical" center is empty, but for him the emptiness is meaningful in itself, it being exactly what the turn to formalism accomplished, the moment of high theory in economics; a turn which, though not preordained, was always already waiting to happen.

What to make of this very interesting book? As I have already indicated, the phenomenological approach is very productive of insights, and the narrative both complements and engages critically with other histories of economics. That in itself makes the book a great occasion for reflection, learning, and teaching. I do have my doubts, however, regarding Düppe's conclusion about the end of economics (both real and desired). It is indeed desirable to look at economics from a certain phenomenological angle (questioning critically the ethos of the economist as scientist), and from that angle it might very well be that

\footnotetext{
${ }^{6}$ I say "supposedly" because I do not myself agree with this characterization. The turn to these research programs seems to me to be a rather domesticated turn, with the neoclassical postulates of maximizing agency (and resulting equilibrating market tendencies) still setting the parameters for the asking of questions and the interpretation of answers.
} 
economic science has ended. But it is quite possible to look at matters from other angles as well (that of the policy maker, that of the public intellectual, that of the political agent, and so on, even through the phenomenological prisms particular to each of these), and to weave a tapestry of economics (even of economic science, I would suppose, if "science" is defined broadly enough) from an intersection of angles. From such an intersection, it might seem less certain that we are seeing, or should be calling for, either the end of "the economy" or the recourse to languages of science.

In suggesting a multiplicity of phenomenological angles and a less certain stance on where we are today, I am not, I think, far from Düppe's own horizons. Düppe opens the book with a description of a 16th century painting (The tax collector) by the Flemish painter Marinus van Reyemerswaele. He focuses on the role of a scribe who, recording entries in a book of accounts, finds himself uncomfortably close to the human drama playing itself out at the intersection of two gazes, that of a powerful tax collector on one side, and that of a supplicant debtor on the other (the one figure inspiring antipathy, the other sympathy, perhaps!).

The scribe's function is to write down, and thus to represent, the transaction. The scribe's own gaze is on his ledger: he is looking down. His "down-gaze", however, Düppe convincingly argues, is not a sign of self-absorption in a taxing task (pun intended); it is, rather, a sign of discreetness, as the scribe eschews a discomforting encounter with the gazes of the economic actors. For Düppe, the scribe is the symbol of what the economist is going to become: the representer of a structured chain of transactions and also, like the scribe of the 16th century, a down-gazer, hiding from the pains, passions, and interests of economic life, hiding behind the curtain of science-and getting authority from that stance.

All well and good! But the story of beginnings does not have to, and should not, end there. As it happens, in 1966 Michel Foucault also opened his own book on the origins of modernity, Les mots et les choses (The order of things), with a description of a painting, a 17th century painting in his case: Las meninas by Diego Velasquez. Like Düppe, Foucault was also concerned with the problem of representation. But Foucault's formulation of the problem was more open ended, more open to multiplicity, than Düppe's. In Las meninas, the field of representation, as Foucault explained laboriously, is not given by (the relations between) 
the represented and the representer. It is given, rather, by the very absence of the representer.

This difference in the field of representation is significant. The difference itself might be explained by the lapsing of a century between the work of van Reyemerswaele and that of Velasquez: in that lapse, one could surmise, art became interested less in the relationship between the subject representing and the object represented, and more in the activity of representation in itself. And, to return to Düppe, we could further surmise that the down-gaze of the scribe upon which he puts so much stake already represents the possibility, if not the inevitability, of the exit of the representer from the scene; the limit to infinity of the "discreetness" Düppe finds in the genome of the economic scientist. We can thus explain the exit of the representer from the scene that Foucault considered so central to modernity. But having explained this exit, we should also consider whether it has consequences. It does, I think. The absence of the representer marks the scene with meaning. It marks it, specifically, with possibility, as an empty space which is not yet occupied by one single point of representation and is thus open to multiple sources (and inspirations and methods) of representation.

The sources of economic science (and in parallel fashion, the sources of the idea of "the economy"), can be presumed to be many. There are imperatives other than, and in addition to, the phenomenological one of the "scientist" for the practice of economics and for the powerconferring concept of "the economy". I will mention, as an example, the work of Timothy Mitchell, who traces the idea of "the economy", in the 20th century (though not earlier) to the colonial relationship between the European and other peoples, and to projects of “development” (Mitchell 2000; 2002).

We could also talk about the imperative of the Keynesian project, or of the Marxian one (in any of their forms) to construct "the economy" as an object of policy (in this respect, Düppe's light treatment of Marx and Keynes is problematic). ${ }^{7}$ Thus, even if we grant that a phenomenological reflection could call for the erasure of the concept of the economy, there are still other sources of meaning to take into

\footnotetext{
${ }^{7}$ Also problematic, perhaps even more so than the light treatment of Keynes, is Düppe's neglect of the Cambridge/capital controversy, and of the alternative theoretical space that controversy kept open for a conception of "the economy", e.g., Marxian (or Ricardian - the reader can pick) in which extra-economic forces are determinants of prices, and which is not structuralist and not conducive to formalism.
} 
account before any settling of accounts could be declared. And this, without even taking into account the effects of the Great Recession on what popular movements and policy makers might, could, would (will?) ask of "the economy" and of economists. To vacate Economics Departments without taking the multiplicity of those latter imperatives into account seems unwise (though, admittedly, they made themselves felt after Düppe's thoughts were formed and it might be unfair to have expected him to foresee them).

I am in full sympathy with the idea that economics is an ideology, and that humanity would benefit from the clipping of its wings. But the struggle for an end of economics and of economic science will play itself out outside of academia as well as within. As powerful as science and philosophy are, the powers they have-the former to propose and the latter to dispose-are not exclusive to them.

\section{REFERENCES}

Mitchell, Timothy (ed.). 2000. Questions of modernity. Minneapolis: University of Minnesota Press.

Mitchell, Timothy. 2002. Rule of experts. Berkeley: California University Press.

Antonio Callari is Sigmund M. and Mary B. Hyman professor at Franklin and Marshall College, Lancaster, Pennsylvania. He has published articles and edited collections on Marxian economics and social theory, and he has contributed methodological and historical essays to edited volumes on The gift, post-colonialism and economics, and on the figure of Robinson Crusoe in economics.

Contact e-mail: <acallari@fandm.edu> 